\title{
DRUŽBENA/SOCIALNA GEOGRAFIJA NA UNIVERZI V LJUBLJANI V LUČI PRETEKLEGA IN SODOBNEGA DOGAJANJA V SLOVENSKI DRUŽBI
}

\author{
dr. Vladimir Klemenčič \\ Oddelek za geografijo, Filozofska fakulteta Univerze v Ljubljani \\ Aškerčeva 2, SI- I000 Ljubljana \\ e-mail: vladimir.klemencic@telemach.net
}

Pregledni znanstveni članek

COBISS 1.02

\section{Izvleček}

V prispevku je predstavljen razvoj socialne geografije $\mathrm{v}$ devetdesetih letih njenega obstoja na ljubljanski univerzi. Ta razvoj je mogoče razdeliti v tri obdobja: (1) dobo tradicionalne geografije; (2) dobo hitre industrializacije in $\mathrm{z}$ njo povezanih procesov urbanizacije ter deagrarizacije, ki so se odražali v spremembah podobe ter funkcije slovenske pokrajine; in (3) obdobje po osamosvojitvi Slovenije, katerega zlasti po vstopu v EU zaznamujejo poskusi uveljavljanja sonaravnega in trajnostnega razvoja.

Ključne besede: socialna geografija, Slovenija, industrializacija, deagrarizacija, urbanizacija, mednarodno sodelovanje

\section{HUMAN/SOCIAL GEOGRAPHY AT THE UNIVERSITY OF LJUBLJANA IN THE LIGHT OF THE PAST AND CONTEMPORARY DEVELOPMENTS IN SLOVENE SOCIETY}

\begin{abstract}
This treatise describes the development of social geography during ninety years of its existence at the University of Ljubljana. This development can be divided into three periods: (1) period of traditional geography; (2) period of fast industrialization in Slovenia and with it the connected processes of urbanization and deagrarization, manifested in dynamic changes in image and function of the Slovene landscape; and (3) period after independence of Slovenia characterized by attempts to introduce sustainable development.
\end{abstract}

Key words: social geography, Slovenia, industrialization, deagrarization, urbanization, international cooperation 


\section{UVOD}

Devetdeset let delovanja geografije na Filozofski fakulteti (deloma tudi na Prirodoslovno-matematični fakulteti) Univerze v Ljubljani je dovolj pomemben jubilej, da slovenski geografi pretresemo stanje stroke na področju družbene/socialne geografije. Namen prispevka ni razglabljati o dilemah družbene/socialne geografije, temveč orisati njen razvoj in stanje na področju teorije ter metodologije in njene uporabnosti v praksi na problemih, ki jih narekujejo dinamični prostorski procesi v slovenski pokrajini.

Že vnaprej naj poudarim, da odklanjam vse dosedanje pogosto izrečene pomisleke o razdvojenosti med splošno in regionalno geografijo ter o sintezni, kompleksni in enotni regionalni geografiji, ki so bolj zavirali kot pospeševali razvoj in modernizacijo slovenske geografije (Vrišer 2007; Ilešič 1979). Razprave o t.i. dilemah slovenske geografije, kot npr. o drobljenju na panoge ali pretirani specializaciji, oziroma obravnavanju le posameznih pojavov, so se v večini primerov pokazale kot neutemeljene. To potrjuje na eni strani razvoj geografije v zadnjih dveh desetletjih, na drugi pa velik interes za študij geografije in možnosti za zaposlovanje sorazmerno velikega števila diplomantov. Ti se po osamosvojitvi Slovenije, kot mi je znano, ne zaposlujejo le kot učitelji v šolah, temveč v različnih poklicih, kot npr. v javni upravi pa tudi kot raziskovalci na negeografskih raziskovalnih inštitucijah. Vedno več geografov je zaposlenih tudi kot univerzitetnih učiteljev na geografskih oddelkih univerz v Ljubljani, Mariboru in Kopru.

V slovenski geografiji se je nekajkrat menjal naziv za družbeno geografijo oziroma geografijo človeka. Najprej je bil do 60. let 20. st. v uporabi naziv antropogeografija, nato naziv družbena geografija, nazadnje pa socialna geografija. Ta se pojavlja samostojno in $\mathrm{v}$ povezavi s fizično ali regionalno geografijo. Ob tem je potrebno omeniti, da sta že ob ustanovitvi ljubljanske univerze leta 1919 bili za geografijo predvideni dve stolici, poleg stolice za fizično geografijo tudi stolica za antropogeografijo.

Ne glede na poimenovanje se je socialna geografija hitro modernizirala na področju teorije, metodologije in aplikacije. Ob uvajanju moderne tehnologije, razvoju tematske kartografije in dopolnjevanju metod terenskega dela je svoje delo tesno navezala na mednarodno sodelovanje $\mathrm{z}$ geografskimi institucijami iz vzhodne in zahodne Evrope, v zadnjih dveh desetletjih pa tudi z geografskimi institucijami v ZDA.

Slovenska socialna geografija je mednarodno primerljiva, kar se kaže v hitri rasti števila znanstvenih prispevkov, objavljenih v uglednih znanstvenih publikacijah doma in tujini. V svojem razvoju je slovenska socialna geografija spremljala, na nekaterih področjih pa celo prehitevala razvoj moderne geografije v tujini. Njen hiter razvoj je bil posledica povezovanja slovenskih socialnih geografov s široko mrežo geografskih institucij v tujini, projektne organiziranosti njenega dela in povezav z delovnimi telesi Mednarodne geografske unije, npr. s komisijo za podeželje, komisijo za politično geografijo, komisijo za urbano geografijo, komisijo za turistično geografijo itd.

K modernizaciji socialne geografije sta od sredine 20. st. pripomogli tudi njena projektna organiziranost in vključevanje $\mathrm{v}$ mednarodno zasnovane terenske raziskave na različnih območjih Slovenije in nekdanje Jugoslavije ter na Poljskem, v Avstriji, Italiji in Nemčiji. Ob spremljanju dosežkov na mednarodnem področju je uspešno razkrivala nove pojavne oblike 
v slovenskem prostoru, ki so jih odpirali dinamični procesi urbanizacije in deagrarizacije, in so se pokazali kot izrazito zaviralen moment $\mathrm{v}$ procesih regionalnega povezovanja na lokalni in evropski ravni. Med takšne gotovo sodijo neskladnost regionalnega razvoja ter funkcija meje in obmejnih območij.

\section{TEMELJNA IZHODIŠČA MODERNE DRUŽBENE/SOCIALNE GEOGRAFIJE}

Socialna geografija je v devetdesetih letih obstoja na ljubljanski univerzi hitro spreminjala vsebino, ustrezno razvoju socialne geografije v svetu in socialno-ekonomskemu razvoju v Sloveniji ter preoblikovanju slovenske pokrajine. Ob teh dinamičnih prostorskih procesih so se odprli številni novi geografski pojavi in problemi, ki so vplivali na preoblikovanje tradicionalne geografije $\mathrm{v}$ moderen in razvejan sistem geografske znanosti. Vzporedno $\mathrm{s}$ tem so se oblikovale in razvijale nove znanstvene panoge, katerim je bil prostor temeljni objekt preučevanja, kot npr. regionalno planiranje, urbanizem, urejanje krajine, ekonomika kmetijstva itd. Poleg omenjenih, se s prostorskimi problemi bolj ali manj obrobno ukvarjajo še antropologija, sociologija in politologija.

Socialno geografijo lahko definiramo kot vedo, ki preučuje vpliv družbe kot aktivnega faktorja geografskega okolja, oziroma povezanost družbeno- in fizičnogeografskih dejavnikov v procesih in zakonitostih, ki vplivajo na preoblikovanje pokrajine. Ali rečeno drugače: izhodišče socialne geografije temelji na sprotnem preučevanju aktualnih prostorskih procesov, ki vedno znova spreminjajo prostorske strukture pokrajin, oziroma delovanje skupin prebivalcev kot osnovnih nosilcev prostorskih funkcij (Ruppert in sod. 1977). To je terjalo nove pristope ter iskanje novih teoretičnih in metodoloških izhodišč, kar je bilo mogoče le na osnovi terenskega dela, zlasti kartiranja rabe tal in anketiranja prebivalstva po naseljih ter ožjih regijah.

Čeprav je bila zgoraj navedena definicija osnovno izhodišče pri socialnogeografskem preučevanju, je kljub stalnim željam po uveljavljanju moderne geografije v Sloveniji pogosto ni bilo mogoče v celoti uveljaviti. Vzrok za to je bilo na eni strani stalno pomanjkanje materialnih pogojev, na drugi pa dejstvo, da so dinamični procesi industrializacije, urbanizacije in deagrarizacije vedno znova odpirali probleme neskladnega regionalno-prostorskega razvoja Slovenije, ki so bili vzrok stalnih sprememb podobe, funkcije in socialno-ekonomske strukture kulturne pokrajine. Zaradi vseh naštetih dejavnikov slovenska socialna geografija ni mogla v zadostni meri upoštevati vseh učinkov novo nastalih sprememb naravnih danosti in podobe pokrajine. Ob spremljanju omenjenih dejavnikov je nastalo več novih delovnih področij v socialni geografiji, npr. regionalno planiranje (Vrišer 1965a), geografija turizma (Gosar 1997; Jeršič 1998), politična geografija (V. Klemenčič 1974), geografija podeželja (M. M. Klemenčič 1974), geografija mest (Vrišer 1965b), varstvo okolja (Špes 1981) itd. Začela so se tudi preučevanja vrste drugih za slovensko pokrajino pomembnih elementov, kot so funkcija meje in obmejnosti (Bufon 1995; Bufon 2002; V. Klemenčič 1978; 1987), problemi enakopravnosti med manjšinami in večinskimi narodi v Sloveniji ter v zamejstvu (Bufon 1992; M. M. Klemenčič in V. Klemenčič 2008; Zupančič 1999), spreminjanje avtarkičnega 
oziroma samooskrbnega kmetijstva $\mathrm{v}$ tržno kmetijsko gospodarstvo in uvajanje bolj ali manj ustrezne evropske gospodarske politike na agrarnem in neagrarnem področju (V. Klemenčič 1986; 1989a; 1989b).

Osvetlitvi in opredelitvi učinkov urbanizacije in deagrarizacije, ki so kazali na vse večje neskladje v regionalno-prostorskem razvoju Slovenije, so se v zadnjih dveh desetletjih kot nadgradnja $\mathbf{v}$ geografskih preučevanjih priključile še raziskave sonaravnega in trajnostnega razvoja, ki tržno zasnovan gospodarski napredek postavljajo v čvrste okoljske in socialne okvire (Plut 2005; Vintar Mally 2007). Ta nova preučevanja temeljijo na medsebojnem povezovanju družbenih in naravnih dejavnikov v geografski danosti, vendar z novim načinom opredeljevanja problemov sedanjih in bodočih razvojnih procesov v pokrajini (Lampič 2000; M. M. Klemenčič, Lampič in Potočnik Slavič 2008; Natek 2007; Špes 1998). Zato zahtevajo izpopolnjevanje metodologije terenskega dela, s čimer prispevajo $\mathrm{k}$ stalnemu razvoju teoretskih osnov in metodologije socialne geografije. To pa geografiji tudi v bodoče zagotavlja njeno uporabnost v praksi, množici diplomantov geografije, ki vsako leto dokončajo študij v Ljubljani, Mariboru in Kopru, pa zagotavlja večje možnosti za zaposlitev. Potreba po takšnem raziskovalnem delu geografov se v družbi že kaže, vendar pri odgovornih $\mathrm{v}$ javni upravi in praksi ni vselej v zadostni meri upoštevana. Zato bo tudi znotraj geografije potrebno poskrbeti za popularizacijo geografije, ki bo zainteresirano javnost 'prisilila' $\mathrm{k}$ upoštevanju rezultatov njenega dela. Za nove prijeme v slovenski socialni geografiji je poleg upoštevanja naravnih danosti pri družbeno-gospodarskem razvoju pomembno tudi dejstvo, da raziskave, pa tudi diplomska dela, magisteriji ali doktorati ne upoštevajo le lokalne ravni (Slovenije), temveč posegajo v širši evropski in tudi svetovni prostor.

Razvoj socialne geografije v Sloveniji je odgovarjal stanju geografije v Sloveniji in v Srednji Evropi, po 80. letih 20. st. pa tudi glede na stanje po svetu. Pri tem naj ponovim, da je ob razpravah o teoriji in metodologiji geografije v Sloveniji nenehno potekala tudi razprava o pravilnosti in nujnosti regionalne, kompleksne in sintezne geografije. Največ pomislekov je bilo v zvezi s specializacijo geografije, oziroma drobljenjem geografije na panoge, s čemer pa sam nisem nikoli soglašal, saj 'logika' narekuje, da le iz analize, povezane s specializacijo, lahko nastane dobra sinteza. Vendar pa sinteza ne sme biti snovana na opisni ravni in temeljiti le na ugotovitvah drugih avtorjev (kompilaciji), še zlasti ne v času razvejane znanosti, novih računalniških tehnologij in dobro oblikovanega geografskega informacijskega sistema.

$\mathrm{V}$ razpravah o t.i. tradicionalni integraciji oziroma specializaciji geografije je potrebno posebej opozoriti na mnenje znanega in uglednega strokovnjaka ter mednarodno priznanega poljskega geografa, akademika Jerzyja Kostrowickega, ki je zavračal klasično regionalno geografijo kot raziskovalno vedo, in sodil, da ima ta lahko le značaj deskriptivne enciklopedične informativne stroke. Menil je tudi, da so sintezne obdelave sicer potrebne, vendar $z$ določenimi izpostavljenimi, bolj ali manj specializiranimi problemi. Tako naj bi se vsaka regionalna obdelava, označena tudi kot regionalna analiza, ki se opira na samostojna raziskovanja ali na sintezo samostojnih raziskav, izogibala enciklopedičnemu pristopu s tem, da naj bi postavila v ospredje določene probleme regije, ali si celo že izbrala in se omejila samo na regijo $\mathrm{z}$ vidika določene regionalne problematike (Kostrowicki 1967). 
V študijskem programu visokošolskega študija sta k povezovanju družbene in fizične geografije poleg razvoja ter uporabe modernih informacijskih sistemov veliko prispevala tudi predmeta geografija okolja in varstvo okolja, v zelo aplikativni obliki pa tudi geografija naravnih nesreč. $\mathrm{V}$ pristopu teh predmetov ni mogoče spregledati tesne povezanosti in soodvisnosti učinkov družbe in naravnih danosti v družbeno-gospodarskem razvoju, ki ogrožajo različne oblike gospodarskega pa tudi negospodarskega delovanja človeka in družbe.

\section{PREGLED RAZVOJA DRUŽBENE/SOCIALNE GEOGRAFIJE V SLOVENIJI}

Za lažje razumevanje nove paradigme v geografiji, ki temelji na osnovnih izhodiščih načel sonaravnega in trajnostnega razvoja, bo nove kvalitetne pristope v sodobnem geografskem preučevanju mogoče razumeti na podlagi kratkega pregleda dosedanjega devetdesetletnega razvoja socialne geografije na ljubljanski univerzi. Ta razvoj lahko razdelimo v tri obdobja:

- dobo tradicionalne geografije;

- dobo hitre industrializacije in z njo povezane urbanizacije, deagrarizacije;

- dobo po osamosvojitvi Slovenije z začetki uveljavljanja sonaravnega in trajnostnega razvoja.

V t.i. obdobje tradicionalne geografije, ki pomeni tudi začetke razvoja slovenske znanstvene geografije, sodijo dela Antona Melika in Svetozarja Ilešiča, ki sta svoje delo opravljala še v pretežno tradicionalni agrarni družbi. Eden od najpomembnejših rezultatov tega obdobja je pet knjig obsegajoča monografija Slovenija Antona Melika (Melik 1935; 1936; 1954; 1957; 1959; 1960; 1963). Monografija, v kateri je predstavljeno celotno slovensko etnično ozemlje, je bila ob pomanjkanju statističnih podatkih zasnovana pretežno na terenskem opazovanju in uporabi tedaj še skromne literature o Sloveniji. V terenska opazovanja, zlasti socialnogeografskih in geomorfoloških vsebin, je Melik sistematično vključeval tudi mlade geografe. Od Melikovih del je potrebno omeniti še Planine v Julijskih Alpah (Melik 1950), ki je prav tako nastalo večinoma na osnovi terenskih opazovanj. Z razdobjem statične agrarne pokrajine je povezano še Ilešičevo delo Sistemi poljske razdelitve na Slovenskem (Ilešič 1950), zasnovano na franciscejskem katastru. Ilešič je kot predavatelj z izdajo skript o gospodarski in prebivalstveni geografiji, antropogeografiji itd. že v prvih letih po drugi svetovni vojni poskrbel za širši vpogled študentov v mednarodno geografijo. Med geografskimi deli, ki vključujejo tudi socialnogeografske dejavnike je potrebno omeniti še Ilešičevo monografijo Gospodarska geografija sveta (Ilešič 1957).

Druga faza razvoja socialne geografije v Sloveniji je potekala v obdobju dinamičnih sprememb prostorskih struktur v Sloveniji pod vplivom hitre industrializacije, urbanizacije in deagrarizacije (V. Klemenčič 1992c). To obdobje je povezano s širitvijo mreže geografskih institucij v Sloveniji, med katerimi je potrebno omeniti nastanek Inštituta za geografijo Univerze v Ljubljani (v nadaljevanju IGU) leta 1960. Ta je svoje raziskovalno delo snoval na konceptu socialne geografije, projektni organiziranosti in mednarodni povezanosti. 
S povezovanjem z nemškimi in avstrijskimi geografi, kot npr. Hansom Bobekom, Wolfgangom Hardkejem in Karlom Ruppertom, iz t.i. 'münchensko-dunajske šole' (Pak 2008) in agrarnogeografsko šolo Poljske akademije znanosti in umetnosti (V. Klemenčič 1980), so se sodelavci IGU preko projekta Sistemi kmetijskega gospodarstva z izrabo zemlje vključili tudi v projekt komisije za agrarne sisteme in rabo tal v državah vzhodne srednje Evrope pri Mednarodni geografski uniji. Socialnogeografska preučevanja razvoja podeželja z nemškimi geografi in raziskave sistemov kmetijstva ter podeželja so bila zasnovana na oblikovanju teoretičnih izhodišč in metod izmenično na izbranih naseljih v Nemčiji, na Poljskem in v Sloveniji in tudi nekaterih drugih območjih nekdanje Jugoslavije. Med take je sodilo tudi terensko raziskovanje območja okolice Ohridskega jezera v Makedoniji (Räumliche Struktur 1980), ki so ga skupaj organizirali geografski oddelek skopske univerze, IGU iz Ljubljane in Gospodarskogeografski inštitut Gospodarsko-ekonomske fakultete iz Münchna.

V okviru projekta Sistemi kmetijskega gospodarstva z izrabo zemlje, so bile opravljene še raziskave vasi Podgorje na Bistriški ravnini (V. Klemenčič 1962; 1965) in Sebeborci v Prekmurju (Jeršič in sod. 1962). V okviru komisije za agrarne sisteme in rabo tal v državah zahodne srednje Evrope pri Mednarodni geografski uniji pa smo skupaj s poljskimi geografi organizirali simpozije v Varšavi na Poljskem in v Dalmaciji, katerih so se udeležili tudi hrvaški in srbski geografi.

V okviru sodelovanja z nemškimi geografi je bilo v med letoma 1951 in 2008 samo v Nemčiji objavljenih 171 znanstvenih prispevkov (Pak 2008). To sodelovanje so omogočili številni stiki, ki so se začeli že v 50. letih 20. st., ko se je na Geografskem inštitutu Tehnične visoke šole v Münchnu na področju socialne geografije izpopolnjeval Vladimir Klemenčič. Med 60. in 80. leti 20. st. so se ne Geografskem inštitutu Ekonomske fakultete v Münchnu kot štipendisti izobraževali še Anton Gosar, Borut Ingolič, Matjaž Jeršič, Jakob Medved, Mirko Pak in Metod Vojvoda (Pak 2008). Vsi, z izjemo B. Ingoliča, so kasneje postali univerzitetni profesorji na ljubljanski univerzi, poleg tega pa so tudi vodili ali sodelovali pri raziskovalnih projektih na IGU.

Že v 70. letih 20. st. je IGU s projektom Ekonomska in neekonomska ocena vpliva človekovih dejavnosti na okolje kot opazovalec sodeloval v komisiji za okolje pri gospodarskem združenju vzhodnoevropskih držav (SEV); koordinatorka za Slovenijo je bila Metka Špes.

$\mathrm{V}$ projektno organiziranost slovenske socialne geografije so bili v različnih oblikah vključeni tudi študentje. Z novim načinom preučevanja geografskih danosti v Sloveniji so se študenti usposabljali za samostojno raziskovalno delo in se na osnovi teh izkušenj uspešno zaposlovali na zunajšolskih inštitucijah. Skoraj redno so učitelji Oddelka za geografijo Filozofske fakultete v Ljubljani organizirali študijske ekskurzije v zamejsko Slovenijo. V zadnjih treh desetletjih pa je bila skoraj vsaka generacija študentov pod vodstvom M. Paka deležna ekskurzije po Nemčiji, na katerih so na terenu predavali profesorji nemških univerz. To je bistveno prispevalo h kvaliteti in širitvi geografskih znanj o družbenih, gospodarskih in drugih geografskih pojavih v kapitalistični družbi.

Na koncu tega drugega obdobja, oziroma od 80. let 20. st. naprej, je geografija širila svoja delovna področja na turistično (Gosar 1997; Jeršič 1998; Mrak 2009) in politično geografijo (Bufon 2001a; 2001b; V. Klemenčič 1992b; Rogelj 2007; Zupančič 1999), ves čas pa je tudi spremljala regionalno planiranje (Černe 2005; 2006; Kušar 2008) in razvoj 
urbanizirane pokrajine (Maribor/Marburg 1994; Vrišer in Rebernik 1993; Vrišer 2000) ter podeželja (M. M. Klemenčič 2005; Vrišer 2005; Kerbler 2008; Potočnik Slavič 2008) itd. Pri tem je potrebno omeniti, da so bili v socialnogeografske raziskave vključeni tudi profesorji geografije s Pedagoške fakultete Univerze v Mariboru. Zanje je IGU tudi organiziral podružnico, ki je nudila mariborskim sodelavcem tehnično pomoč pri zbiranju in obdelavi statističnih podatkov ter pripravi tematskih zemljevidov.

Rezultati dela socialnih geografov z Oddelka za geografijo Filozofske fakultete v Ljubljani so vzbudili interes tujih znanstvenikov iz Avstrije, Poljske in ZDA za izobraževanje v Ljubljani, ki so po povratku v domovino doktorirali in nekateri pozneje postali ugledni univerzitetni profesorji, npr. Volker Albrecht iz Nemčije in Andreas Moritsch iz Avstrije. $\mathrm{Na}$ Oddelku za geografijo so se izpopolnjevali in doktorirali iz socialnogeografske tematike tudi kandidati iz drugih območij nekdanje Jugoslavije. Nekateri doktorandi iz Bosne in Hercegovine (Bakaršić 1960; Jelić 1964), Hrvaške (Banović 1983; Mikačić 1984), Kosova (Krasnići 1969; Isljami 1976), Makedonije (Gramatikovski 1968) in Srbije (Vidanović 1958) so kasneje postali univerzitetni profesorji.

Slovenija je v zadnjih treh desetletjih 20. st. predstavljala tudi eno od središč srečanj uglednih geografov in to tako iz držav zahodne kot tudi iz vzhodne Evrope. Ugledni geografi kot npr. Jerzy Kostrowicki s Poljske, Wolfgang Hardke in Karl Ruppert iz Nemčije, Hans Bobek iz Avstrije, Giorgio Valussi iz Italije, Vsevolod A. Anučin in Julian Sauškin iz Rusije so ob srečanjih v Sloveniji predavali tudi študentom.

Pogosti stiki slovenskih geografov s predstavniki geografskih inštitucij evropskih držav so bili vzrok, da so geografi iz zahodne Evrope v času demokratizacije Slovenije in ob prizadevanjih za njeno neodvisnost ter mednarodno priznanje hoteli pridobiti čim več informacij o razmerah v Sloveniji. Tako so bili slovenski socialni geografi povabljeni na vrsto predavanj v tujini. Načrtovano in usklajeno akcijo za promocijo Slovenije v tujini so koordinirali Vladimir Klemenčič v Švici, Nemčiji in Italiji, Mirko Pak v Nemčiji ter Anton Gosar v Avstriji, Nemčiji in ZDA. Program je bil izveden v obliki vabljenih predavanj na univerzah v Švici, Avstriji, Nemčiji, Italiji, ZDA in drugih državah. Z izbrano vsebino so slovenski geografi zainteresirani tuji javnosti osvetlili geopolitični položaj Slovenije na stičišču alpskega, panonskega, dinarskega in mediteranskega sveta, gospodarski in politični položaj v Sloveniji ter povezanost Slovenije z zahodno Evropo na gospodarskem, kulturnem in znanstvenem področju. V zvezi s tem so slovenski geografi objavili med letoma 1989-92 $\mathrm{v}$ tujih znanstvenih revijah 82 prispevkov, ki so pomembno prispevali k promociji Slovenije v mednarodni javnosti (Dolgan-Petrič 1994; V. Klemenčič 1993).

Ob sodelovanju Antona Gosarja so bile v obliki posebne številke mednarodno ugledne geografske revije GeoJournal predstavljene geografske danosti Slovenije za njeno samostojnost (Slovenia 1994). Še pred mednarodnim priznanjem Slovenije smo ob koordinaciji Mirka Paka skupaj s frankfurtskimi geografi organizirali poseben simpozij o Sloveniji. Med referati, ki so bili posebej pripravljeni za utemeljitev upravičenosti samostojnosti in mednarodnega priznanja Slovenije, je potrebno omeniti v slovenskem, nemškem in angleškem jeziku objavljen referat o geopolitičnem položaju Slovenije (V. Klemenčič 1992a; 1992b; V. Klemenčič in Genorio 1993). 
Za zadnjo fazo razvoja slovenske geografije, ki sega v čas po osamosvojitvi Slovenije, je značilno, da so socialni geografi Oddelka za geografijo Filozofske fakultete v Ljubljani nadaljevali delo na večini področij socialne geografije. Pri raziskovalnem in pedagoškem delu je mogoče zaznati vedno večjo povezanost med fizično in socialno geografijo. To še posebej prihaja do izraza ob raziskavah aktualnih prostorskih problemov socialnogeografskega razvoja Slovenije in poskusih uveljavljanja sonaravnega ter trajnostnega razvoja.

Še bolj se je razširilo mednarodno sodelovanje. Vzpostavljene so bile nove povezave z geografskimi institucijami na območjih zunajevropskih razvitih in nerazvitih dežel, ki se ukvarjajo predvsem z geografskimi pojavi, ki so po svoji vsebini tudi predmet visokošolskega izobraževanja. Omeniti je potrebno tudi stopnjevano samostojnost pri raziskovalnem delu posameznikov in skupin študentov, kar se kaže v posebni študentski publikaciji Geomix.

Raziskovalno delo slovenskih socialnih geografov je mednarodno primerljivo, kar se kaže tudi v izmenjavi študentov, oziroma $v$ interesu študentov tujih univerz za študij na Oddelku za geografijo, kot tudi v interesu študentov Oddelka za geografijo za študij v tujini. Iz revije Geomix je tudi razvidno, da študentje s samostojno organiziranimi akcijami kažejo interes za spoznavanje tujega geografskega okolja in to tako v Evropi kot tudi na drugih kontinentih, $s$ tem pa tudi interes za povezovanje $\mathrm{z}$ mednarodnimi študentskimi organizacijami. To kaže, da učitelji geografije različnih smeri uspešno ustvarjajo na Oddelku za geografijo novo jedro mladih geografov. $\mathrm{Z}$ organiziranim podiplomskim in doktorskim študijem so ti že zagotovili ali zagotavljajo novo generacijo univerzitetnih učiteljev tudi pri predmetih socialnogeografskih vsebin. Pri tem pa vendarle pogrešamo večjo usklajenost učiteljev posameznih predmetov ob snovanju vsebin diplomskih in magistrskih del ter doktoratov. Takšna usklajenost bi verjetno še bolj pospešila razvoj socialne geografije na področju teorije in metodologije, kar bi prispevalo $\mathrm{k}$ večji uporabnosti spoznanj slovenske socialne geografije $\mathrm{v}$ praksi. To pa bi zagotavljalo večjo zaposljivost geografov na številnih novih poklicnih področjih, ki se ukvarjajo s problemi stopnjevanega družbenega razvoja ob spremenjenih družbeno-političnih razmerah po osamosvojitvi Slovenije in njeni vključitvi v Evropsko unijo. Poizkusi odprave prostorskih problemov z ukrepi, usklajenimi z evropsko politiko odpirajo vedno nove in nove probleme. Za razliko od preteklosti so se slovenski socialni geografi novih problemov, ki vplivajo na preoblikovanje slovenske pokrajine, lotili z moderno tehnologijo. Za to obdobje je v metodologiji značilna težnja po notranji interdisciplinarnosti same geografije in po čim tesnejšem povezovanju raziskovalnega in tudi pedagoškega dela $\mathrm{z}$ drugimi strokami.

Socialni geografi so za dosežke pri razvoju geografije prejeli številna mednarodna priznanja, ki so bila rezultat njihovega dolgoletnega intenzivnega sodelovanja z geografskimi institucijami v tujini. Več slovenskih geografov, npr. Ivan Gams, Anton Gosar, Svetozar Ilešič, Vladimir Klemenčič, Anton Melik in Mirko Pak, je bilo izvoljenih za častne člane nemškega, avstrijskega, italijanskega in poljskega geografskega društva ter geografskih društev drugih republik nekdanje Jugoslavije. Za dosežke na področju urbane geografije je Mirko Pak prejel častni doktorat univerze v Pécsu na Madžarskem. Vladimir Klemenčič in Igor Vrišer sta za svoje znanstveno delo prejela nagrado sklada Borisa Kidriča, Svetozar Ilešič in Anton Melik pa sta prejela najvišji jugoslovanski priznanji, nagrado AVNOJ-a, za življenjsko delo pa nagradi Borisa Kidriča. Za dolgoletne raziskovalne dosežke, s katerimi 
sta prispevala k povečanju mednarodne uveljavitve Republike Slovenije, še posebej v času prizadevanj za mednarodno priznanje Slovenije, sta Anton Gosar in Vladimir Klemenčič prejela priznanje Ministrstva za znanost in tehnologijo Republike Slovenije - Ambasador Republike Slovenije v znanosti.

\section{ZAKLJUČEK}

Pregledne bibliografije, ki bi celovito predstavila razvoj slovenske socialne geografije, ni na razpolago. Vlogo in vsebinski razvoj socialne geografije na Oddelku za geografijo Filozofske fakultete v Ljubljani in na IGU je tako mogoče razbrati le iz posebnih bibliografij, ki so jih bibliotekarke knjižnice Oddelka za geografijo pripravile ob posameznih okroglih jubilejih geografskih inštitucij ali posameznih geografov. Tem jubilejem so bile posvečene tudi posamezne številke revij Geografski vestnik, Dela in Geographica Slovenica. Delno predstavo o razvoju slovenske geografije kot celote in o razvoju socialne geografije na področju teorije, metodologije in njene aplikacije je mogoče dobiti tudi iz seznama doktorskih disertacij in magistrskih del, ki so v devetdesetih letih obstoja geografije nastala na Univerzi v Ljubljani, in iz seznama bibliografij posameznih sodelavcev Oddelka za geografijo.

Obsežno opravljeno delo v tiskanih publikacijah ter v obliki diplomskih, magistrskih in doktorskih del bi bilo lahko dobra osnova za skupni projekt ali program učiteljev in sodelavcev geografije, ki bi nosil naziv Sonaravni in trajnostni razvoj Slovenije. Ta bi lahko bil dopolnilo dosedanjih spoznanj učinkov procesov družbeno-ekonomskega razvoja Slovenije kot celote ali njenih posameznih delov.

Ker je delo na socialni geografiji v celotnem devetdesetletnem razdobju njenega obstoja zelo obsežno in diferencirano po različnih delovnih področjih v okviru sistema geografske znanosti, se že vnaprej opravičujem vsem, ki so prispevali k razvoju socialne geografije in jih v tej predstavitvi nisem imenoval ali pa njihovo delo predstavil v pomanjkljivi obliki. Sam menim, da bi zaradi izjemne širine lahko vlogo slovenske socialne geografije pri razvoju teorije, metodologije in aplikacije na domači in mednarodni ravni celovito ovrednotila šele posebna in poglobljena študija. Posebej bi moral biti ovrednoten tudi prispevek slovenskih geografov pri seznanjanju mednarodne javnosti v času demokratizacije Slovenije in njenih prizadevanj za samostojnost in mednarodno priznanje.

Ob zaključku naj še pripomnim, da v prispevku, kljub pomembnosti, ni posebej opisana dejavnost socialnih geografov v poljudnem publicističnem delu in nekaterih drugih oblikah popularizacije geografije v medijih.

\section{Viri in literatura}

Bakaršić, S. 1960: Postanak i razvitak Sarajeva. Doktorska disertacija. Oddelek za geografijo, Filozofska fakulteta Univerze v Ljubljani. Ljubljana.

Banović, B. 1983: Iseljavanje iz Jugoslavije i jugoslavenska imigracija na Novom Zelandu.

Neki pokazatelji i obilježja migracije u razdoblju 1900-1971. Doktorska disertacija. Oddelek za geografijo, Filozofska fakulteta Univerze v Ljubljani. Ljubljana. 
Bufon, M. 1992: Prostorska opredeljenost in narodna pripadnost. Obmejna in etnično mešana območja v evropskih razvojnih silnicah: primer Slovencev v Furlaniji-Julijski krajini. Založništvo tržaškega tiska. Trst.

Bufon, M., 1995: Prostor, meje, ljudje. Razvoj prekomejnih odnosov, struktura obmejnega območja in vrednotenje obmejnosti na Goriškem. Slovenski raziskovalni inštitut. Trst.

Bufon, M., 2001a: Osnove politične geografije 1: razvoj politične geografije in geopolitike, globalne razvojne teze ter politična geografija držav in drugih politično-teritorialnih enot. Oddelek za geografijo Filozofske fakultete. Ljubljana.

Bufon, M. 2001b: Osnove politične geografije 2: meddržavni odnosi, globalizacija, problematika prostorskega in družbenega razmejevanja, politične meje in mejni spori, meje v Sloveniji, maritimne meje ter politična geografija prihodnosti. Oddelek za geografijo Filozofske fakultete. Ljubljana.

Bufon, M. 2002: Confini, identità ed integrazione: nuove prospettive per l'Alto Adriatico. Slovenski raziskovalni inštitut. Trst.

Černe, A. 2005: Regionalne razlike in regionalno planiranje. Dela 24, str. 125-136. Ljubljana.

Černe, A. 2006: Regional development and systems of spatial planning in SE Europe. V: Structural analysis of spatial and human sources for interregional cooperation in Southeast Europe, Slovenia and Austria. Oddelek za geografijo Filozofske fakultete, str. 28-71. Ljubljana.

Dolgan-Petrič, M. 1994: Vloga slovenske geografije v mednarodni promociji Slovenije. Bibliografija v tujini objavljenih del slovenskih geografov 1989-1994. Oddelek za geografijo Filozofske fakultete Univerze v Ljubljani in Inštitut za geografijo Univerze. Ljubljana.

Gosar, A. 1997: Der Tourismus im Alpen-Adriaraum. Lage in Slowenien und Kroatien unter geopolitischen Aspekten. V: Slowenien, Kroatien, Bosnien-Herzegowina. Neue Staaten am Rande Mitteleuropas. Beiträge zur Angewandten Sozialgeographie 37, str. 65-79. Augsburg.

Gramatikovski, V. 1968: Vlijanie na novite socio-ekonomski odnosi na promenata na agrarna struktura i agrarnoto proizvodstvo vo Severna Prespa. Doktorska disertacija. Oddelek za geografijo, Filozofska fakulteta Univerze v Ljubljani. Ljubljana.

Ilešič, S. 1950: Sistemi poljske razdelitve na Slovenskem. Slovenska akademija znanosti in umetnosti. Ljubljana.

Ilešič, S. 1957: Afrika, Južna Azija, Avstralija z Oceanijo in južnim polarnim svetom. Državna založba Slovenije. Ljubljana.

Ilešič, S. 1979: Pogledi na geografijo. Partizanska knjiga. Ljubljana.

Isljami, H. 1976: Najnoviji regionalno-demografski procesi Kosova kao nacionalno mešovito područje. Doktorska disertacija. Oddelek za geografijo, Filozofska fakulteta Univerze v Ljubljani. Ljubljana.

Jelić, D. 1964: Kraška pokrajina izmedju Ljubomira i Orjena te njeni prirodni i društveni uslovi razvoja. Doktorska disertacija. Oddelek za geografijo, Filozofska fakulteta Univerze v Ljubljani. Ljubljana. 
Jeršič, M. 1998: Bližnja rekreacija prebivalcev Slovenije. Geographica Slovenica 29. Ljubljana.

Jeršič, M., Lojk, J., Olas, L., Vojvoda, M. 1962: Kmetijska proizvodnja in izraba tal v vasi Sebeborci v Prekmurju. Geografski vestnik 34, str. 81-97. Ljubljana.

Kerbler, B. 2008: Dejavniki nasledstva na hribovskih kmetijah v Sloveniji. Knjižnica Annales Majora. Založba Annales. Koper.

Klemenčič, M. M. 1974: Socialnogeografska transformacija podeželja na primeru vzhodne Gorenjske. Geographica Slovenica 3, str. 90-102. Ljubljana.

Klemenčič, M. M. 2005: Nova razvojna strategija pokrajinsko homogenih obrobnih območij Slovenije. Dela 24, str. 185-193. Ljubljana.

Klemenčič, M. M., Lampič, B., Potočnik Slavič, I. 2008: Življenjska (ne)moč obrobnih podeželskih območij v Sloveniji. Zbirka GeograFF 3. Znanstvena založba Filozofske fakultete, Oddelek za geografijo. Ljubljana.

Klemenčič, M., Klemenčič, V. 2008: The endeavors of Carinthian Slovenes for their ethnic survival with/against Austrian governments after World War II. Mohorjeva založba. Celovec, Ljubljana, Dunaj.

Klemenčič, V. 1962: Kmetijska proizvodnja in izraba tal v vasi Podgorje pri Kamniku. Geografski vestnik 34, str. 62-81. Ljubljana.

Klemenčič, V. 1965: The village of Podgorje in the Slovenian sub-alpine region. Geographia Polonica 5, str. 195-214. Warszawa.

Klemenčič, V. 1974: Odprta meja med Jugoslavijo in Italijo in vloga manjšin. Teorija in praksa 11, 9-10, str. 928-936. Ljubljana.

Klemenčič, V. 1978: Grenzregionen und nationale Minderheiten. Geographica Slovenica 8, str. 7-20. Ljubljana.

Klemenčič, V. 1980: The problems of the semi-agrarian structure in the semi-urban zones of Slovenia. Geographica Slovenica 11, str. 9-21. Ljubljana.

Klemenčič, V. 1986: O položaju slovenske geografije. Geografski vestnik 48, str. 3-7. Ljubljana.

Klemenčič, V., 1987: Državna meja na območju SR Slovenije in obmejna območja kot nov geografski fenomen. Razprave in gradivo 20, str. 57-79. Ljubljana.

Klemenčič, V. 1989a: Med antropogeografijo in socialno geografijo na ljubljanski univerzi. Dela 6, 22-29. Ljubljana.

Klemenčič, V., 1989b: Oddelek za geografijo. Zbornik Filozofske fakultete v Ljubljani, 19191989, str. 113-117. Ljubljana.

Klemenčič, V. 1992a: Državna meja na območju R Slovenije in mejna območja kot nov geografski fenomen. Teoretične in metodološke osnove proučevanja meja in obmejnosti. V: Seminar za študije geopolitičnega položaja Slovenije. Slovenski svetovni kongres, str. 81-105. Ljubljana.

Klemenčič, V. 1992b: Die geopolitische Lage Sloweniens und seine Offenheit nach Europa. Staatliche Einheit und Teilung - Deutschland und Slowenien. Südosteuropa-Aktuell 14, str. 99-114. München.

Klemenčič, V. 1992c: Slovenija in Slovenci danes ter jutri v luči socialne geografije. Geographica Slovenica 23, str. 37-57. Ljubljana. 
Klemenčič, V. 1993: Slovenski geografi v tujem znanstvenem tisku. Geografski obzornik 40, 2, str. 3. Ljubljana.

Klemenčič, V., Genorio, R. 1993: The new state of Slovenia and its function within the frame of Europe. GeoJournal 30, 3, str. 323-333. Dordrecht.

Kostrowicki, J. 1967: Zagadnenie specializacji i integracji w geografii ekonomicznej. Przegląd Geograficzny 39, 1, str. 13-32. Warszawa.

Krasnići, M. 1960: Društveno-geografske promene na Kosovu i Metohiji u socialističkoj izgradnji 1945-1958. Doktorska disertacija. Oddelek za geografijo, Filozofska fakulteta Univerze v Ljubljani. Ljubljana.

Kušar, S. 2008: Vloga prostorskega planiranja pri lociranju proizvodnih dejavnosti v Sloveniji. Doktorska disertacija. Oddelek za geografijo, Filozofska fakulteta Univerze v Ljubljani. Ljubljana.

Lampič, B. 2000: Izbrani razvojni in okoljevarstveni problemi slovenskega podeželja z vidika sonaravnega razvoja. Geographica Slovenica 33, 1, str. 157-202. Ljubljana.

Maribor/Marburg. Prispevki h geografiji prijateljskih mest v Sloveniji in Nemčiji. Pedagoška fakulteta Univerze v Mariboru. Maribor 1994.

Melik, A. 1935: Slovenija. Geografski opis. 1. Splošni del, 1. zvezek. Slovenska matica. Ljubljana.

Melik, A. 1936: Slovenija. Geografski opis. 1. Splošni del, 2. zvezek. Slovenska matica. Ljubljana.

Melik, A. 1954: Slovenija. Geografski opis. II. Opis slovenskih pokrajin, 1. zvezek: Slovenski alpski svet. Slovenska matica. Ljubljana.

Melik, A. 1950: Planine v Julijskih Alpah. Slovenska akademija znanosti in umetnosti. Ljubljana.

Melik, A. 1957: Slovenija. Geografski opis. II. Opis slovenskih pokrajin, 2. zvezek: Štajerska s Prekmurjem in Mežiško dolino. Slovenska matica. Ljubljana.

Melik, A. 1959: Slovenija. Geografski opis. II. Opis slovenskih pokrajin, 3. zvezek: Posavska Slovenija. Slovenska matica. Ljubljana.

Melik, A. 1960: Slovenija. Geografski opis. II. Opis slovenskih pokrajin, 4. zvezek: Slovensko primorje. Slovenska matica. Ljubljana.

Melik, A. 1963: Slovenija. Geografski opis. 1. Splošni del, 2. predelana izdaja. Slovenska matica. Ljubljana.

Mikačić, V. 1984: Jugoslavenski doseljenici u Australiji s posebnim osvrtom na razvoj etničke naseobine na metropolitanskom području Sydneya. Doktorska disertacija. Oddelek za geografijo, Filozofska fakulteta Univerze v Ljubljani. Ljubljana.

Mrak, I. 2009: Sonaravni razvoj turizma in rekreacije v visokogorju. Doktorska disertacija. Oddelek za geografijo, Filozofska fakulteta Univerze v Ljubljani. Ljubljana.

Natek, K. 2007: Geografske dimenzije naravnih nesreč in varstva pred njimi. Dela 28, str. 147-164. Ljubljana.

Pak, M. 2008: Kooperation slowenischer und deutscher Geographen. V: Slowenien. Transformationen und kleinräumige Vielfalt. Natur - Raum - Gesellschaft 5. Institut für Humangeographie, str. 318-330. Frankfurt am Main.

Plut, D. 2005: Teoretična in vsebinska zasnova trajnostno sonaravnega napredka. Dela 23, str. 59-113. Ljubljana. 
Potočnik Slavič, I. 2008: Endogeni razvojni potenciali podeželja. Doktorska disertacija. Oddelek za geografijo, Filozofska fakulteta Univerze v Ljubljani. Ljubljana.

Räumliche Struktur- und Prozessmuster in der SR Makedonien. Münchner Studien zur Sozial- und Wirtschaftsgeographie 20. Kallmünz/Regenburg 1980.

Rogelj, B. 2007: Bosnia and Herzegovina between Dayton regionalization and post-Dayton centralization. V: Regions in the process of European integration. Region and Regionalism 8, 2, str. 153-164. Opole.

Ruppert, K., Schaffer, F., Maier, J., Paesler, R. 1977: Sozialgeographie. Georg Westermann Verlag. Braunschweig.

Slovenia. Papers recently published in GeoJournal including a selection of studies presented to the IGU Symposium on Ethnicity and geography, Ljubljana, September 8-11, 1993. GeoJournal 33, 4. Dordrecht 1994.

Špes, M. 1981: Problemi življenjskega okolja v Celju. Geographica Slovenica 12, str. 167-191. Ljubljana.

Špes, M. 1998: Degradacija okolja kot dejavnik diferenciacije urbane pokrajine. Geographica Slovenica 30. Ljubljana.

Vidanović, G. S. 1958: Vidlić - Zabrdje. Prilog poznavanju privrednog tipa i razvitka i razmeštaja proizvodnje jedne zaostale periferne kraške oblasti. Doktorska disertacija. Oddelek za geografijo, Filozofska fakulteta Univerze v Ljubljani. Ljubljana.

Vintar Mally, K. 2007: Trajnostni izzivi Evrope v 21. stoletju. Dela 28, str. 239-253. Ljubljana.

Vrišer, I. 1965a: Regija v prostorskem planiranju. Urbanizem 3, 4-6, str. 102-115. Ljubljana Vrišer, I. 1965b: Geografska izhodišča pri omejevanju mest in njihovih vplivnih območij. Geografski vestnik 37, str. 143-161. Ljubljana.

Vrišer, I. 2000: Industrijska geografija (univerzitetni učbenik). Oddelek za geografijo Filozofske fakultete. Ljubljana.

Vrišer, I. 2005: Ocena vrednosti kmetijske proizvodnje v Republiki Sloveniji (na podlagi popisa kmetijskih gospodarstev leta 2000 in povprečnih odkupnih cen leta 2003). Dela 24, str. 7-22. Ljubljana.

Vrišer, I. 2007: Geografske dileme. Geografski vestnik 79, 1, str. 77-84. Ljubljana.

Vrišer, I., Rebernik, D., 1993: Družbenogospodarska in dejavnostna usmeritev slovenskih mest. Geografski zbornik 33, str. 7-40. Ljubljana.

Zupančič, J. 1999: Slovenci v Avstriji. Geographica Slovenica 32. Ljubljana.

\section{HUMAN/SOCIAL GEOGRAPHY AT THE UNIVERSITY OF LJUBLJANA IN THE LIGHT OF THE PAST AND CONTEMPORARY DEVELOPMENTS IN SLOVENE SOCIETY}

\section{Summary}

The development of social geography in Slovenia can be divided into three periods: (1) period of traditional geography; (2) period of fast industrialization in Slovenia and with it connected processes of urbanization and deagrarization; and (3) period after independence 
of Slovenia and its entering and membership in the European Union. We have to emphasize that when the University of Ljubljana was established in 1919, there were two chairs foreseen: one for physical geography and one for human geography (anthropogeography)

The first period encompasses the beginnings of Slovene scientific geography. The social geographers emphasized research on development of settle-ments and agrarian geography. During this period some basic work on geography of Slovenia was done.

The characteristics of the second period were the dynamic changes in the Slovene landscape, consequences of fast industrialization and with it connected deagrarization and urbanization. These dynamic spatial processes opened numerous new geographical phenomena and problems, which influenced geography in Slovenia to develop from traditional geography into a modern, well-developed system of geographic fieldwork and scholarship. In the framework of this development many new fields opened up (regional planning, geography of tourism, political geography, geography of the countryside, urban geography, etc.).

This was also a period of modernization of social geography in the fields of theory, methodology, and application. Research work was based on projects; it was also based on field research and it followed interdisciplinary patterns. In more and more numerous cases the Slovene social geographers were also included in international cooperation with foreign geographical institutions (field research, common projects, symposia, exchange of visiting professors, etc.). Slovene geographers also intensively cooperated with geographical institutions of the republics of former Yugoslavia and commissions of the IGU.

The tradition of many years of cooperation with representatives of foreign geographical institutions enabled Slovene geographers to give many invited lectures in foreign countries (Switzerland, Austria, Germany, Italy, USA, and others) during the period of democratization of Slovenia and endeavors for its independence. During the crucial years 1989-92, Slovene geographers published ninety-two scientific papers from different fields of geography that were important for promotion of Slovenia as an independent state.

During the third phase, after the independence of Slovenia, Slovene social geographers started to connect with other geographic institutions in regions outside Europe, developed and less developed countries alike. Research work of Slovene geographers has been more and more harmonized with the process of teaching geography at the university level, with other subjects taught at the university, and also as a result of international cooperation. A characteristic of Slovene geography in the latest period is also quite a great deal of intermingling between physical and social geography, especially when the Slovene geographers deal with the contemporary problems of socio-economic development of Slovenia and attempts to introduce sustainable and close-to-nature managed development, which market-oriented economic development put into a vigorous environmental and social framework.

Slovene social geographers received numerous international awards for their achievements in development of geography, results of their long intensive cooperation with geographic institutions outside Slovenia. Many Slovene geographers were named honorary members of German, Austrian, Italian and Polish geographical societies and geographical societies of other republics of former Yugoslavia. 